\title{
ANTIQUITY, ORIGINAL SIZE AND LOCATION OF PRAIRIE DOG TOWNS IN WIND CAVE NATIONAL PARK
}

\author{
Everett M. White \\ Plant Science Department (Soils) \\ South Dakota State University \\ Brookings
}

\section{Objectives}

To describe and interpret soil morphology and properties in selected prairie dog mounds in order to estimate the length of time the mound has been in use and support this estimate with $\mathrm{C}^{14}$ dates if stratigraphically identifiable organic materials are available in the mounds.

\section{Methods}

Soil colors, structure, and development were described by standard soil classification procedures for soils along transects across three mounds. Soil samples were collected from the morphological distinct layers, crushed, screened $(<2 \mathrm{~mm})$, and selected samples analyzed in the laboratory. These results are being plotted on scaled cross-sectional figures at the respective mounds to aid in interpreting the stratigraphy. Laboratory analysis completed were saturation water percentage, conductivity, $\mathrm{pH}$, total $\mathrm{N}$, total organic matter, and total phosphorus. Standard methods were used.

\section{Results}

Two mounds in Area 1 along the north central boundary of the park were sampled. Remnants of the original soil buried by the mound were found. This soil had some characteristics of having been formed under forest. Habitation of the area by prairie dogs may have occurred during one of the dry climatic intervals when the forest receeded and prairie advanced in the Black Hills. The buried soil, which presumably had been leached of carbonates, contained seams of secondary carbonates that occupied boundaries between the peds (soil structure units). Theoretical curves have been prepared relating leaching of carbonates to time, however these curves are dependent on the $\mathrm{CaCO}_{3}$ content of the soil parent material. Thus, age estimates cannot be made until the $\mathrm{CaCO}_{3}$ content of the soil are determined.

One mound was sampled in Area 2 near the east side of the park. The area is on a terrace with a clayey fluvial mantel that was separated from the underlying reddish-colored shale by a layer of lag cobbles. This lag may have impeded burrowing to concentrate prairie dog mounds at locations where it was penetrated. The original soil on the fluvial layer was found beneath the mound only within a short distance from the ege of the mound. Fluvial sediment below 
the central part of the mound had been mixed with reddish shale, presumably dug from below the cobbles. Apparently, the mound had grown horizontally so the original terrace soil was around the edges of the mound and destroyed by mixing in the center part. The possibility the mound was constructed initially before the soil was formed in the terrace cannot be excluded. At least a large amount of mixing of the two materials has occurred that may afford an estimate of the mound age based on the amount of material prairie dogs bring to the surface each year, the number of tunnel entrances which could be expected as the mound grew in size, and the total volume of material in the mound. Because the mixing has been so complete, estimating the age by $\mathrm{C}^{14}$ dating or by leaching of carbonates seems unlikely.

\section{Conclusions}

More definitive conclusions will be possible in the fourth quarterly report after the laboratory analysis are tabulated in a more interpretable form. Although very tenative, Area 1 has had more intermittant prairie dog use than Area 2, possibly as a result of the advance and retreat of forest into the prairie of Area 1. Area 2 has almost two inches less annual precipitation than Area 1 and probably has been in prairie for most of the Holocene. Prairie dogs may have been present for most of this epoch. 